\title{
Zróżnicowanie, pojawianie się i powracanie patogenów wirusowych: przeszłość, teraźniejszość, przyszłość
}

\section{STRESZCZENIE}

W rusy $\mathrm{i}$ choroby wirusowe od dekad znajdują się w centrum zainteresowania nauki, a niektóre z naszych największych wyzwań i osiągnięć dotyczą zagadnień wirusologii. Przypadki nowo pojawiających się i nawracających zakażeń stanowią istotny problem i niekiedy ogromne wyzwanie dla zdrowia publicznego. Pomimo znacznych postępów w zrozumieniu biologii patogenów, molekularnych mechanizmów patogenezy, przełomów $w$ profilaktyce tych zakażeń oraz ich wpływu na zdrowie publiczne i gospodarkę światową, pojawianie się nowych wirusów pandemicznych pozostaje nie do końca wyjaśnione. Niniejsza praca przeglądowa prezentuje aktualny stan wiedzy na temat nowo pojawiających się infekcji wirusowych na świecie - $w$ tym m.in. ostatnich epidemii SARS-CoV-2, MERS, ZIKV - omawiając ich możliwe pochodzenie, ewolucję, naturalny rezerwuar, mechanizmy adaptacji do organizmu człowieka oraz potencjalne czynniki ryzyka.

\section{WPROWADZENIE}

Wirusy i choroby wirusowe od dekad znajdują się w centrum zainteresowania nauki, rolnictwa i medycyny, a niektóre z naszych największych wyzwań i triumfów dotyczą właśnie wirusologii. Wielokrotnie od czasów starożytnych przypadki nowo pojawiających się oraz nawracających zakażeń znacząco wpływały na zdrowie ludzi. Ospa prawdziwa jest tego najlepszym przykładem: największy zabójca ludzkości, który dosłownie zmienił bieg historii podczas podboju Nowego Świata przez Europę, jest również jedyną chorobą, którą dotychczas udało się skutecznie eradykować na świecie. To niezwykłe osiągnięcie było możliwe dzięki wykazaniu w 1796 r. przez Edwarda Jennera, że szczepienie zmianami chorobowymi krowianki zapewnia ochronę przed znacznie bardziej zjadliwym wirusem ospy prawdziwej. Prowadzone przez Światową Organizację Zdrowia (ang. World Health Organization, WHO) globalne wysiłki w zakresie szczepień przeciwko ospie prawdziwej zaowocowały zwalczeniem tej choroby w październiku 1979 r. [1].

Na przestrzeni wielu lat ogromne wyzwania w dziedzinie zdrowia publicznego związane były z epidemiami wywoływanymi przez wirusy zakażające układ oddechowy człowieka. Na początku XX wieku pandemia grypy "Hiszpanki” wywołana nowym mutantem wirusa H1N1 była odpowiedzialna za większą liczbę ofiar śmiertelnych aniżeli trwająca wówczas pierwsza wojna światowa [2]. Kolejne pandemie grypy znane jako grypa "azjatycka” (1957-1958) oraz grypa „Hong Kong" (1968-1970) odpowiedzialne były za śmierć łącznie $\sim 3$ milionów ludzi [2]. Ostatnia pandemia "świńskiej grypy" miała miejsce w 2009 r. a liczba ofiar śmiertelnych wynosiła $>18000$ [3]. Chociaż choroby zakaźne i związana z nimi śmiertelność zmniejszyły się, pozostają znaczącym zagrożeniem na całym świecie. W większości krajów zapobiega się lub kontroluje wiele ostrych infekcji wirusowych poprzez powszechne szczepienia oraz poprawę warunków sanitarnych, higieny, dostępności czystej wody, odżywiania, praktyk medycznych i systemów opieki zdrowotnej. W rezultacie epidemie wirusowe, takie jak odra, wścieklizna i żółta febra, są obecnie rzadkie w krajach rozwiniętych. Niektóre choroby zakaźne np. malaria - nadal występują endemicznie na wielu obszarach, powodując znaczące i stałe obciążenie. Inne, takie jak grypa, dotyczą zarówno regionów rozwijających się, jak i rozwiniętych oraz podlegają wahaniom pod względem powszechności i liczby rejestrowanych przypadków prowadzących do ognisk epidemicznych (gwałtownego wzrostu częstości występowania na stosunkowo ograniczonym obszarze lub populacji), epidemii (gwałtownego wzrostu liczby przypadków obejmujący większy obszar lub populację ) lub pandemii (epidemii obejmującej wiele krajów lub kontynentów). W odniesieniu do zdrowia publicznego znaczenie mają przede wszystkim epidemie wywoływane przez wirusy zakażające człowieka. Należy jednak podkreślić, że wirusy powodują również poważne choroby roślin i zwierząt gospodarskich wpływając negatywnie na rolnictwo i przemysł hodowlany. Epidemia pryszczycy w Wielkiej

\section{dr n. med. Agnieszka Figas ${ }^{\varpi}$}

Dział Medyczny, MSD Polska

https://doi.org/10.18388/pb.2020_359

凶autor korespondujący: agnieszka.figas@ merck.com

Słowa kluczowe: adaptacja, ewolucja, gospodarz, patogen, pojawiający się, wirus

Wykaz skrótów: BBLV - wirus wścieklizny nietoperzy Bokeloh (ang. Bokeloh Bat Lyssavirus); BKV - ludzki poliomawirus BK (ang. human polyomavirus BK); BSE - gąbczasta encefalopatia bydła (ang. Bovine Spongiform Encephalopathy); CCHF - wirus gorączki krwotocznej krymsko-kongijskiej (ang. Crimean-Congo haemorrhagic fever virus); CHIKV - wirus Chikungunya (ang. Chikungunya virus); DENV - wirus Denga (ang. Dengue virus); ECDC - Europejskie Centrum ds. Zapobiegania i Kontroli Chorób (ang. European Centre for Disease Control and Prevention); FMDV - wirus pryszczcy (ang. Foot-and-mouth disease virus); FUGV - wirus Fugong (ang. Fugong virus); HEV - wirus zapalenia wątroby typu E (ang. Hepatitis E virus); HIV - wirus niedoboru odporności (ang. human immunodeficiency virus); hMPV - ludzki metapneumowirus (ang. human metapneumovirus); HTNV - wirus Hantaan (ang. Hantaan virus); JCV - ludzki poliomawirus JC (ang. human polyomavirus JC); MCV - Merkel cell polyomavirus; MERS-CoV - wirus bliskowschodniego zespołu niewydolności oddechowej (ang. Middle-East respiratory syndrome coronavirus); $\mathrm{MeV}$ - wirus odry (ang. measles virus); NTD -zaniedbane choroby tropikalne (ang. neglected tropical diseases); RABV - wirus wścieklizny (ang. Rabies virus); R\&D - badania i rozwój (ang. research and development); SARS-CoV - wirus ciężkiego ostrego zespotu niewydolności oddechowej (ang. severe acute respiratory syndrome coronavirus); SNV - wirus Sin Nombre (ang. Sin Nombre virus); TTV wirus Torque Teno (ang. Torque Teno virus); WHO - Światowa Organizacja Zdrowia (ang. World Health Organization); WNV - wirus gorączki Zachodniego Nilu (ang. West Nile virus); VEEV - wirus wenezuelskiego końskiego zapalenia mózgu (ang. Venezuelan equine encephalitis virus); ZIKV - wirus ZIKA (ang ZIKA virus) 


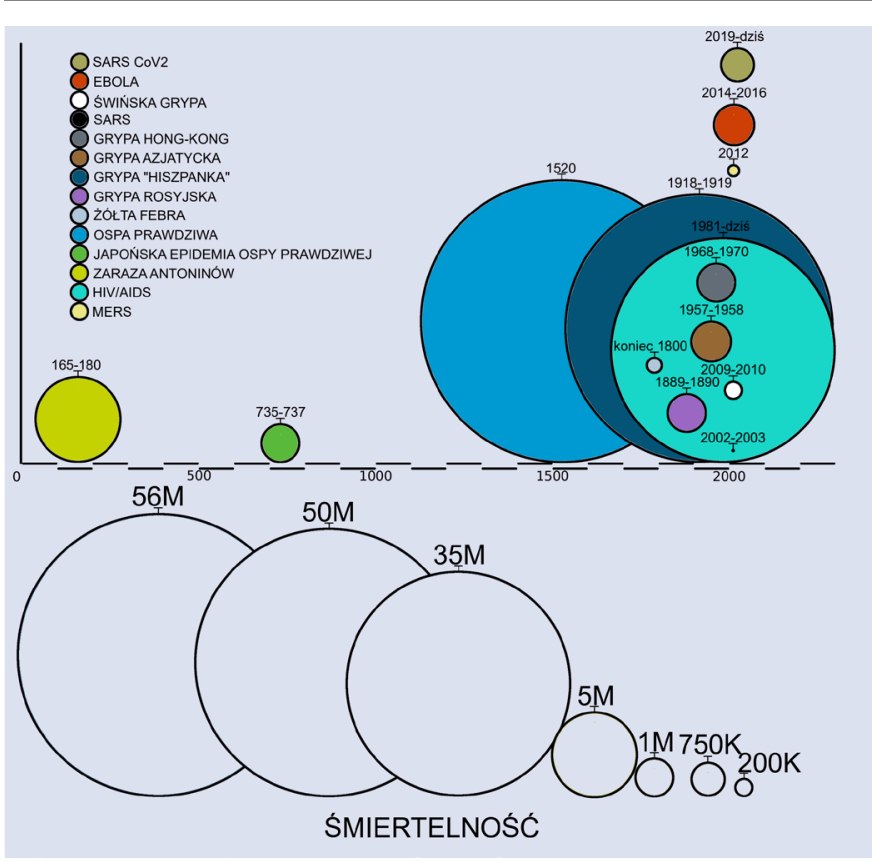

Rycina 1. Historia światowych pandemii.

Brytanii z 2001 r. zdewastowała przemysł hodowli bydła. Wirus ospy śliwkowej, który od początku XX wieku dziesiątkował drzewa pestkowe w Europie, rozprzestrzenił się aktualnie na Stany Zjednoczone i Kanadę. Wirusy są zaangażowane również $\mathrm{w}$ rozwój chorób niszczących pszczoły miodne, zagrażając naturalnym cyklom zapylania, a tym samym większości rolnictwa. Rycina 1 przedstawia szczegółowo historię światowych pandemii o etiologii wirusowej.

Początkowo uwaga wirusologów skupiała się głównie na wirusach jako czynnikach chorobotwórczych, jednak w tej dziedzinie nadal dokonuje się znaczny postęp. W latach osiemdziesiątych XX wieku odkrycie ludzkiego wirusa niedoboru odporności (ang. human immunodeficiency virus, HIV) zwiększyło ogólnoświatową świadomość i zainicjowało zainteresowanie badawcze nowo pojawiającymi się patogenami wirusowymi. Występujące nowe ogniska zakażeń doprowadziły do odkrycia wachlarza różnorodnych wirusów należących m.in. do rodzin Arenaviridae, Bunyaviridae, Filoviridae, Paramyxoviridae, Coronaviridae, Hepeviridae, Togaviridae. Wśród nich znajdują się: ludzkie poliomawirusy BKV, JCV i $\mathrm{MCV}$; hantawirusy wirus Hantaan oraz wirus Sin Nombre. Zidentyfikowano śmiertelne przypadki gorączek krwotocznych wywołanych przez arenawirusy tj. wirus Lujo (Afryka Południowa, 2008 r.) oraz wirus Lassa (Gwinea, Liberia, 2009 r.; Ghana 2011 r.; Benin 2014 r.) [4,5]. Wśród nowych wirusów wywołujących ostre infekcje oddechowe zidentyfikowano w 2001 r. w Holandii ludzki metapneumovirus (ang. human metapneumovirus, hMPV), a w 2013 r. w Chinach nowy szczep wirusa ptasiej grypy A/H7N9 [6,7]. We wrześniu 2012 r. nowy koronawirus MERS-CoV (ang. Middle-East respiratory syndrom coronavirus, MERS-CoV) został wyizolowany od pacjenta w Arabii Saudyjskiej, który zmarł na ostrą chorobę układu oddechowego i niewydolność nerek. Obraz kliniczny przypominał przypadki obesrowane podczas epidemii w latach 2002-2003 wywołanej koronawirusem SARS-CoV (ang. severe acute respiratory syndrome coronavirus, SARS-CoV) [8]. Obecnie jednym z większych wyzwań dotyczących zdrowia publicznego jest trwająca pandemia wywołana nowym koronawirusem SARS-CoV-2, który po raz pierwszy wyizolowano w grudniu 2019 r. w mieście Wuhan w Chinach [9]. Według aktualnych danych Europejskiego Centrum ds. Zapobiegania i Kontroli Chorób (ang. European Centre for Disease Control and Prevention, ECDC) w okresie od 31.12.2019 do 12.08.2020 globalna liczba potwierdzonych przypadków zakażeń wywołanych SARS-CoV-2 wynosi 20330 351, w tym 742413 zgonów [10].

Pomimo znacznych postępów $\mathrm{w}$ zrozumieniu biologii patogenów, molekularnych mechanizmów patogenezy, przełomów w profilaktyce tych zakażeń oraz ich wpływu na zdrowie publiczne i gospodarkę światową, pojawianie się nowych wirusów pandemicznych pozostaje nie do końca wyjaśnione. Niniejsza praca przeglądowa prezentuje aktualny stan wiedzy na temat nowo pojawiających się infekcji wirusowych na świecie, omawiając ich możliwe pochodzenie, ewolucję, naturalny rezerwuar, mechanizmy adaptacji do organizmu człowieka oraz potencjalne czynniki ryzyka.

\section{POCHODZENIE ODZWIERZĘCE LUDZKICH WIRUSÓW}

Pojawiający się patogen można zdefiniować jako czynnik sprawczy choroby zakaźnej, której częstość występowania wzrasta wraz z pojawieniem się w nowej populacji żywicieli lub której częstość wzrasta $\mathrm{w}$ istniejącej populacji żywicieli w wyniku długoterminowych zmian leżących u podstaw jej epidemiologii [11]. Jednym z potencjalnych źródeł pojawiającego się patogenu jest inny gatunek żywiciela tj. "rezerwuar". Spośród nowo pojawiających się lub powracających patogenów wirusowych zakażających ludzi >70\% znajduje rezerwuar pośród zwierząt. Są to głównie ssaki hodowlane oraz drób, rzadziej żyjące na wolności zwierzęta i stawonogi $[11,12]$. Wiedza dotycząca zoonotycznego charakteru patogenów oraz różnorodności wirusów w ich naturalnym rezerwuarze jest jednak ograniczona. Dane dotyczące niektórych ssaków domowych i dzikich zwierząt będących rezerwuarem dla wielu gatunków patogenów są niewystarczające [13]. Istnieje wiele przykładów nowo pojawiających się wirusów związanych z zoonozą np. nowe szczepy wirusa grypy, ludzkie koronawirusy, lyssawirusy.

Według aktualnych danych, na świecie kilka gatunków ssaków uznawanych jest za potencjalny rezerwuar hantawirusów. Każdy z serotypów wirusa ma swoisty rezerwuar w pospolitych gryzoniach: wirus Hantaan - mysz polną Apodemus agrarius, Seoul - szczura wędrownego Rattus norvegicus, Puumala - nornice Myodes glareolus i M. rutilus oraz mysz domową Mus musculus, natomiast wirus Dobrava/ Belgrad - mysz leśną Apodemus flavicollis [14]. W 2012 r. w Chinach zidentyfikowano nowego hantawirusa - wirusa Fugong (ang. Fugong virus, FUGV) u małych ssaków z rodziny chomikowatych tj. rdzawoplecyk Eothenomys eleusis [15]. Hantawirusy wykryto również u ryjówek i nietoperzy, ale ich potencjalny związek z chorobami ludzi wciąż pozostaje niewyjaśniony.

Zmiany w różnorodności żywicieli dotyczą również wirusa zapalenia wątroby typu E (ang. Hepatitis E virus, HEV). 
Oprócz ludzi oraz świń istnieje rosnący łańcuch ssaków będących żywicielami HEV obejmujący: jelenie, dziki, mangusty, króliki, szczury, kozy, wielbłądy, nietoperze, fretki, łosie $[16,17]$. Podobna sytuacja dotyczy bardzo rozpowszechnionego wirusa Torque Teno (TTV), należącego do nowo ustalonej rodziny wirusów, Anelloviridae, który zakaża również świnie, krowy, owce, psy, koty, psy i kury [18,19].

Arbowirusy, takie jak wirus Denga (ang. Dengue virus, DENV), wirus Chikungunya (ang. Chikungunya virus, CHIKV), wirus ZIKA (ang. ZIKA virus, ZIKV) i wirus gorączki Zachodniego Nilu (ang. West Nile virus, WNV), przenoszone przez stawonogi, pojawiły się ponownie $\mathrm{w}$ wielu regionach tropikalnych i subtropikalnych w ciągu ostatnich dwóch dekad. Należy podkreślić również, że pierwotnie zachorowania wywołane przez ZIKV znane były jako przypadki zaniedbanych chorób tropikalnych (ang, neglected tropical disease, NTD), które ograniczały się głównie do Afryki i Azji. Wirus ZIKV rozszerzył swoje terytorium geograficzne wywołując epidemie w 2007 r. na wyspie Yap oraz w latach 2013-2014 na wyspach Pacyfiku [20,21]. Aktualnie, wśród arbowirusów, wirus gorączki Zachodniego Nilu pozostaje najistotniejszym czynnikiem etiologicznym odpowiedzialnym za zapalenia mózgu w Ameryce Północnej, z udziałem w swoim cyklu transmisji komarów z rodzaju Culex sp. oraz drozda wędrownego Turdus migratorius. Adaptacyjne zmiany genetyczne genomu WNV ułatwiają mu rozprzestrzenianie się w całym regionie Ameryki Północnej. Pośród pojawiających się i powracających arbowirusów warto wymienić również wirusa gorączki krwotocznej krymsko-kongijskiej (ang. Crimean-Congo haemorrhagic fever virus, CCHF) będącej zoonozą wirusową przenoszoną przez kleszcze, występującą w Afryce, Azji, Europie Wschodniej i na Bałkanach. Szeroki zasięg geograficzny koreluje z zasięgiem głównego wektora wirusa tj. kleszczy należących do rodzaju Hyalomma. Znaczenie cyklu kleszcz-kręgowiec-kleszcz dla utrzymania przenoszenia wirusa jest dobrze znane. Małe ssaki są uważane za ważnych gospodarzy namnażających wirusa. Zwierzęta gospodarskie wykazują łagodne objawy kliniczne choroby lub nie wykazują ich wcale, ale rozwijają krótki okres wiremii, podczas którego wirus może zostać przeniesiony na ludzi. Pojawienie się CCHF od 2002 r. w kilku krajach na Bałkanach budzi obawy, że wirus ten może rozszerzyć swoje obecne rozmieszczenie geograficzne i ustanowić nowe ogniska endemiczne [22].

Aktualne dane wskazują, że nietoperze są siedliskiem różnorodnych patogenów wirusowych. Lyssawirusy należące do rodziny Rhabdoviridae to zoonotyczne, neutropowe ludzkie patogeny odpowiedzialne za zmiany zapalne mózgu. Spośród 14 wyodrębnionych gatunków lyssawirusów 12 wyizolowano od nietoperzy. Analiza sekwencji nukleotydowych lyssawirusów w odniesieniu do sekwencji referencyjnych wykazała dotychczas występowanie różnych gatunków lyssawirusów z odrębnymi cyklami krążenia. U nielatających ssaków zarówno wolno żyjących, jak również domowych, występuje gatunek pierwszy lyssawirusów wirus wścieklizny (ang. Rabies virus, RABV), podczas gdy u nietoperzy wykrywany jest głównie gatunek 5 - EBLV1. W październiku 2016 roku u nietoperza z gatunku nocek Natterera (Myotis nattereri) wyizolowano po raz pierwszy w Polsce gatunek 14 tj. wirus wścieklizny nietoperzy Bokeloh (ang. Bokeloh Bat Lyssavirus, BBLV). BBLV po raz pierwszy wyizolowano w Niemczech w 2010 roku, a następnie w 2012 roku we Francji [23]. Pierwotnym rezerwuarem ludzkich koronawirusów SARS-CoV oraz MERS-CoV wywołujących epidemie były również nietoperze. Ekspozycja wirusa na inne gatunki zwierząt doprowadziła do przekroczenia bariery międzygatunkowej. W obu przypadkach proces transmisji wirusa z nietoperza na człowieka obejmował nosiciela pośredniego, którymi był łaskun palmowy dla SARS-CoV i wielbłąd jednogarbny dla MERS-CoV [24,25]. Przypuszcza się, że wywołujący aktualną pandemię SARS-CoV-2 podobnie jak jego poprzednicy pochodzi od nietoperzy, natomiast kwestia nosiciela pośredniego nadal pozostaje niejasna [26].

\section{EWOLUCJA, PRZEKROCZENIE BARIERY GATUNKOWEJ I ADAPTACJA}

Analizy filogenetyczne pozwalają wnioskować, że wirusy, których genom stanowi kwas deoksyrybonukleinowy (DNA) ewoluowały i różnicowały się przez miliony lat [27]. Uważa się, że większość wirusów, których materiałem genetycznym jest kwas rybonukleinowy (RNA) ma znacznie nowszą historię ewolucji. Warto zauważyć, że okres ich adaptacji do człowieka wynosi zaledwie kilka tysięcy lat [28]. Wirusy RNA zawdzięczają większe zróżnicowanie genetyczne podatnej na błędy polimerazie RNA/odwrotnej transkryptazie. Wskaźniki błędów polimerazy DNA zostały dobrze scharakteryzowane $\mathrm{w}$ różnych gatunkach i warunkach środowiskowych i są niskie, rzędu jednej mutacji na $10^{-8}-10^{-10}$ par zasad na cykl replikacyjny. W przeciwieństwie do tego błędy polimerazy RNA mają wyjątkową pozycję do generowania większej różnorodności fenotypowej. Wskaźniki błędów polimerazy RNA są wysokie i wynoszą $10^{-6}-10^{-5}$ [29].

O zjawisku przekraczania bariery międzygatunkowej mówi się wtedy, gdy dany patogen wywołuje zakażenie w organizmie nowego gospodarza należącego do innego gatunku. Aby zrozumieć ten proces należy szczegółowo rozważyć mechanizmy dotyczące biologii „skoku”. Pierwszy etap obejmuje ekspozycję nowego gatunku żywiciela na działanie patogenu. Tempo narażenia jest funkcją ekologii i zachowania dwóch gatunków żywicieli oraz biologii przenoszenia samego patogenu (w tym biologii wektorów zaangażowanych). Większość przypadków pojawiania się chorób np. BSE czy wirusowego zapalenia wątroby typu C było związane ze zmianą "ekologii” [40]. W przypadku chorób wektorowych narażenie nowych gatunków żywicieli może być ułatwione przez transmisję patogenu między nowymi gatunkami wektorów, jak sugerowano w przypadku wirusa wenezuelskiego końskiego zapalenia mózgu (ang. Venezuelan equine encephalitis virus, VEEV) [30].

Drugi etap obejmuje możliwość skutecznego zakażenia nowego żywiciela. Patogeny wirusowe mają bardzo zróżnicowane zakresy żywicieli. Niektóre naturalnie infekują tylko jeden gatunek np. wirus świnki (ang. Measles virus, MEV) zakaża tylko człowieka, podczas gdy inne mogą zakażać żywicieli z różnych klas taksonomicznych np. wirus wścieklizny. Przyczyny tej zmienności pozostają słabo poznane, chociaż wiadomo, że niektóre czynniki, takie jak pośrednia droga przenoszenia, są związane z szerokim zakresem ży- 
wicieli. W przypadku wirusów jednym z takich czynników jest wykorzystywanie receptorów komórkowych, które są ewolucyjnie konserwatywne. Do skutecznego zakażenia kluczowa jest obecność odpowiednich receptorów na powierzchni komórek gospodarza. Gdy receptory o wysokim stopniu konserwatywności występują w szeregu potencjalnych gatunków, jest prawdopodobne, że żywiciele będą predysponowani do zakażenia wirusami wykorzystującymi te receptory. Na przykład użycie konserwatywnych receptorów może wyjaśnić szeroki zakres gospodarzy wirusa pryszczycy (FMDV), który wykorzystuje receptor integrynowy oraz wirusa wścieklizny, który wykorzystuje receptor nikotynowy acetylocholiny [31]. Warto podkreślić, że nawet jeśli dojdzie do skutecznego zakażenia nowego gatunku żywiciela patogeny te są przeważnie, choć istnieją też wyjątki, mniej zakaźne, co jest związane ze zjawiskiem istnienia tzw. bariery gatunkowej. W praktyce oznacza to, że zwykle do infekcji nowego gospodarza wymagane są wyższe dawki zakaźne [40]. Badania eksperymentalne przeprowadzone przez francuskich badaczy wykazały, że dawki zakaźne wirusa wścieklizny izolowanego od lisów potrzebne do zakażenia np. psów czy kotów muszą być wyższe nawet milion razy [32]. Ostatni etap skutecznego pokonania bariery międzygatunkowej obejmuje wystarczającą zdolność patogenu wirusowego do transmisji między osobnikami w nowej populacji gospodarza.

Na proces adaptacji prowadzący do ustanowienia stabilnych linii wirusów w populacji człowieka mają wpływ takie czynniki jak: mutacje punktowe w obrębie genomu wirusa (np. parwowirus psi), reasortacja (np. wirus grypy H5N1) lub rekombinacja pomiędzy genomem wirusa i gospodarza $[33,34]$. Przykładem rekombinantów genetycznych wirus-gospodarz jest wyizolowany w $2011 \mathrm{r}$. z materiału klinicznego genotyp 3 wirusa HEV, zdolny do zakażania w warunkach in vitro hepatocytów człowieka, świni i jelenia [35]. Pomyślny proces adaptacji organizmu nowego gospodarza warunkują m.in. czynniki, takie jak: liczba pierwotnych zakażeń, liczba zakażeń w nowej populacji, liczba mutacji i innych zmian genetycznych oraz prawdopodobieństwo ich wystąpienia. Dziedzina filodynamiki łącząca modelowanie dla danych dotyczących gospodarza, epidemiologii i biologii molekularnej w przypadku wirusów RNA wydaje się być szczególnie obiecująca.

\section{CZYNNIKI POWODUJĄCE POJAWIANIE SIĘ I POWRACANIE WIRUSÓW ZAKAŻAJĄYCH CZŁOWIEKA}

Zidentyfikowano kilka głównych czynników powodujących pojawienie się i powracanie ludzkich patogenów wirusowych. Pojawianie się chorób zakaźnych w regionach dotychczas wolnych od zakażeń spowodowane jest głównie transmisją wirusa poprzez handel międzynarodowy i podróże. Natomiast uważa się, że za ogniska zakażeń występujące lokalnie odpowiedzialne jest połączenie zmian środowiskowych i społecznych. Najnowszym przykładem może być tu aktualnie trwająca pandemia wywołana przez wirus SARS-CoV-2, która została zapoczątkowana w mieście Wuhan (Chiny, prowincja Hubei) w grudniu 2019 r., a obecnie przypadki zakażeń zidentyfikowano w 210 krajach [10]. Podobna sytuacja dotyczyła pojawienia się ZIKV w Brazylii w 2015 roku. Analizy filogenetyczne wskazują, że ZIKV z wysp Pacyfiku (odpowiedzialny za epidemię w latach 2013-2014) został zawleczony do Brazylii prawdopodobnie podczas Mistrzostw Świata FIFA2014 lub Mistrzostw Świata w sprincie kajakowym w Rio de Janeiro. Transmisja ZIKV na terenie Brazylii spowodowała epidemię gorączki ZIKA, która rozprzestrzeniła się na inne kraje z powodu częstych podróży [36].

Warto podkreślić, że na szybkość przenoszenia wirusa ma również wpływ gęstość zaludnienia populacji - wyższa zwykle ułatwia rozprzestrzenianie patogenu. Chociaż wiadomo, że wiele chorób zakaźnych ludzi ma charakter zoonotyczny, to zdecydowaną większość można określić jako choroby "tłumu", które wymagają dużej gęstości gospodarzy aby przetrwać. W szczególności niedawne ogniska i epidemie: wirusa grypy H1N1, wirusa Hendra, wirusa Nipah, MERS-CoV oraz SARS-CoV-2 sugerują, że region Azji i Pacyfiku może być punktem zapalnym do pojawiania się nowych wirusów RNA. Szacunki dotyczące jednego takiego zdarzenia na 100 lat pozostają spójne $\mathrm{z}$ historią demograficzną tego regionu [37,41].

Do pozostałych czynników wpływających na pojawianie się i powracanie patogenów ludzkich należą: zmiany w użytkowaniu gruntów i praktykach rolniczych, zły stan zdrowia populacji (np. HIV, niedożywienie), ewolucja patogenów (mechanizmy oporności, zwiększona wirulencja), hospitalizacja i procedury medyczne, zanieczyszczanie źródeł pożywienia i wody oraz niepowodzenie programów zdrowia publicznego [38].

\section{PRZYSZŁE WYZWANIA}

Niewątpliwie ekspozycja i ewolucja są siłami napędowymi prowadzącymi do różnorodności ludzkich patogenów wirusowych. Być może największym wyzwaniem w przewidywaniu epidemii i skutecznym reagowaniu jest szeroki wachlarz możliwych przyczyn, w tym patogeny, które są obecnie nieznane. Od 2016 r. WHO publikuje listę chorób wymagających pilnej uwagi działu badawczo-rozwojowego. Lista chorób priorytetowych według planu koncentruje się na pojawiających się poważnych chorobach, które mogą spowodować stan zagrożenia zdrowia publicznego i dla których nie istnieją żadne rozwiązania zapobiegawcze i lecznicze lub są one niewystarczające. Kryteria priorytetyzacji obejmują m.in.: możliwość przenoszenia choroby przez ludzi, dostępność medycznych środków zaradczych, dotkliwość lub śmiertelność przypadków, relacje między człowiekiem a zwierzętami, kontekst zdrowia publicznego na dotkniętym obszarze, potencjalne skutki społeczne i potencjał ewolucyjny. Obecnie lista ta obejmuje takie jednostki chorobowe jak: zespół ostrej niewydolności oddechowej COVID-19, gorączki krwotoczne: krymsko-kongijska, Ebola, Marburg oraz Lassa, Bliskowschodni zespół niewydolności oddechowej MERS, ciężki ostry zespół niewydolności oddechowej SARS, choroba Nipah, gorączka doliny Rift, ZIKA oraz ",choroba X". Według WHO choroba X oznacza, że poważna ogólnoświatowa epidemia może być spowodowana przez patogen, który obecnie nie wywołuje choroby u ludzi. Plan badawczo-rozwojowy wyraźnie dąży do umożliwienia wczesnej gotowości w zakresie R\&D (badania i roz- 
wój, ang. research and development), która jest również istotna w przypadku nieznanej „choroby X" [39].

Aktualne wyzwania obejmują również prowadzenie stałego nadzoru epidemiologicznego, dostęp do szybkiej i skutecznej diagnostyki oraz rozwój nowych terapii. Niewątpliwie istnieje ogromna potrzeba prowadzenia dalszych prac naukowych mających na celu nie tylko opracowanie środków zaradczych, ale również zrozumienie biologii nowych patogenów wirusowych i potencjalnej wrażliwości człowieka na zakażenie.

\section{PODSUMOWANIE}

Przykłady nowo pojawiających się i powracających patogenów wirusowych znacząco wpłynęły na zdrowie ludzi pomimo ogromnego postępu w dziedzinie nauk medycznych i biologicznych. Wysoka gęstość zaludnienia, różnice $\mathrm{w}$ zapewnieniu odpowiednich warunków sanitarnych oraz zmiany w praktykach rolniczych wpływają na selektywną presję na żywicieli i rezerwuar patogenów. Ogromnym wyzwaniem dla zdrowia publicznego mogą stać się zatem wirusy, które dotychczas nie powodowały zakażeń u ludzi. Nieprzewidywalny charakter nowych infekcji, bezobjawowe występowanie oraz pojawianie się przypadków na obszarach oddalonych mogą znacznie utrudniać kontrolę i stosowanie środków zapobiegawczych. Z tego względu istotne dla zdrowia publicznego są wspólne działania obejmujące swym zakresem: system opieki zdrowotnej - poprzez poprawę współpracy i koordynacji między organizacjami (np. WHO, Gavi, krajowe ośrodki kontroli chorób, producenci leków itp.), prowadzenie skutecznego nadzoru nad chorobami zakaźnymi, rozwój badań naukowych oraz formułowanie opartych na dowodach zaleceń dotyczących zarządzania globalnym ryzykiem związanym z chorobami zakaźnymi.

\section{PIŚMIENNICTWO}

1. Centers for Disease Control and Prevention. History of smallpox. https://www.cdc.gov/smallpox/history/history.html

2. Wever PC, van Bergen L (2014) Death from 1918 pandemic influenza during the First World War: a perspective from personal and anecdotal evidence. Influenza Other Respir Viruses 8: 538-546

3. Dawood FS, Iuliano AD, Reed C, et al. (2012) Estimated global mortality associated with the first 12 months of 2009 pandemic influenza A H1N1 virus circulation: a modelling study. Lancet Infect Dis 12: 687-695

4. World Health Organization (2017) Lassa fever Fact Sheet. https:// www.who.int/news-room/fact-sheets/detail/lassa-fever

5. Sewlall NH, Richards G, Duse A (2014) Clinical Features and Patient Management of Lujo Hemorrhagic Fever. PLoS Neg Trop Dis doi: 10.1371/journal.pntd.0003233

6. Van de Hoogen B, de Jong J, Groen J et al (2001) A newly discovered human pneumovirus isolated from young children with respiratory tract disease. Nat Med 7: 719-724.

7. Li Q, Zhou L, Zhou M et al. (2014) Epidemiology of human infections with avian influenza A(H7N9) virus in China. N Engl J Med 370: 520532

8. Khan G (2013) A novel coronavirus capable of lethal human infections: an emerging picture. Virol J doi: 10.1186/1743-422X-10-66

9. Zhu H, Niu P (2020) The novel coronavirus outbreak in Wuhan, China. Glob Health Res Policy doi: 10.1186/s41256-020-00135-6
10. European Centre for Disease Control and Prevention (2020) COVID-19 situation update, as of 12 August 2020. https:/ / www.ecdc.europa.eu/ en/geographical-distribution-2019-ncov-cases

11. Woolhouse M, Dye C (2001) Population biology of emerging and reemerginh pathogens - preface. Philos Trans R Soc Lond Ser B 356: 981 982

12. Cleaveland S, Laurenson MK, Taylor LH (2011) Diseases of humans and their domestic mammals: pathogen characteristics, host range and the risk of emergence. Phil Trans R Soc Lond B 356: 991-999

13. Cleaveland S, Haydon DT, Taylor L (2007) Overviews of pathogen emergence: which pathogens emerge, when and why? Curr Top Microbiol Immunol 315: 85-111

14. Baumann-Popczyk A, Sadkowska-Todys M (2014) Choroby hantawirusowe, W: Baumann-Popczyk A, Sadkowska-Todys M, Zieliński A (red) Choroby zakaźne i pasożytnicze - epidemiologia i profilaktyka. Wydawnictwo a-medica Press, str. 73-79

15. Ge X, Yang W, Pan H, et al. (2016) Fugong virus, a novel hantavirus harbored by the small oriental vole (Eothenomys eleusis) in China. Virol J, 13: 27-32

16. Pavio N, Meng XJ, Doceul V (2015) Zoonotic origin of hepatitis E. Curr Opin Virol 10: 34-41. Widén F (2016) Hepatitis E as a zoonosis. Adv Exp Med Biol 948: 61-71

17. Okamoto $H$, Takahashi M, Nishizawa T, Tawara A, Fukai $K$, et al (2002) Genomic characterization of TT viruses (TTVs) in pigs, cats and dogs and their relatedness with species-specific TTVs in primates and tupaias. J Gen Virol 83: 1291-1297

18. Niel C, Diniz-Mendes L, Devalle S (2005) Rolling-circle amplification of Torque teno virus (TTV) complete genomes from human and swine sera and identification of a novel swine TTV genogroup. J Gen Virol 86: 1343-1347

19. Brassard J, Gagné MJ, Lamoureux L, Inglis GD, Leblanc D, et al. (2008) Molecular detection of bovine and porcine Torque teno virus in plasma and feces. Vet Microbiol 126: 271-276

20. Duffy M R, ChenT-H et al. (2009) Zika virus outbreak on Yap Island, Federated States of Micronesia. New Eng J Med 360: 2536 - 2543

21. Calvez E, Mousson L, Vazeille M, O'Connor O, Cao-Lormeau V-M, Mathieu-Daude' F et al. (2018) Zika virus outbreak in the Pacific: Vector competence of regional vectors. PLoS Negl Trop Dis https:/ / doi.org/10.1371/ journal.pntd.0006637

22. Burt F, Goedhals D (2014) Crimean-Congo Haemorrhagic Fever Virus, an Emerging and Re-Emerging Pathogen, W: Sing A. (red) Zoonoses - Infections Affecting Humans and Animals. Springer, Dordrecht. https://doi.org/10.1007/978-94-017-9457-2_39

23. Orłowska A, Smreczak M, Trębas P et al. (2017) Aktualna sytuacja epizoonotyczna wścieklizny w Polsce $z$ analizą filogenetyczną krajowych szczepów lyssawirusów. IV Lubelskie Dni Wirusologiczne, 2017

24. Cui J, Li F, Shi ZL (2019) Origin and evolution of pathogenic coronaviruses. Nat Rev Microbiol 17: 181-92

25. Khan S, Siddique R, Shereen MA, Ali A, Liu J, Bai Q, Bashir N, Xue $M$ (2020) The emergence of a novel coronavirus (SARS-CoV-2), their biology and therapeutic options. J Clin Microbiol 58: pii: e00187-2

26. Lu R, Zhao X, Li J, Niu P, Yang B, Wu H, et al. (2020) Genomic characterization and epidemiology of 2019 novel coronavirus: implications for virus origins and receptor binding. Lancet 395: 565-574

27. Simmonds P (2011) Reconstructing the origins of human hepatitis viruses. Phil Trans R Soc Lond B 356: 1013-1026

28. Kitchen A, Shackelton LA, Holmes EC (2011) Family level phylogenies reveal modes of macroevolution in RNA viruses. Proc Natl Acad Sci USA 108: 238-243

29. Carey L (2015) RNA polymerase errors cause splicing defects and can be regulated by differential expression of RNA polymerase subunits. eLife doi: 10.7554/eLife.09945

30. Weaver SC, Barrett AD (2004) Transmission cycles, host range, evolution and emergence of arboviral disease. Nat Rev Microbiol 2: 789-801

31. Baranowski E, et al. (2001) Evolution of cell recognition by viruses. Science 292: 1102-1105 
32. Blancou J, Aubert MF (1997) Transmission du virus de la rage: importance del la barrière d'espèce. Bull Acad Natl Méd 181: 301-312

33. Hueffer K, et al. (2003) The natural host range shift and subsequent evolution of canine parvovirus resulted from virus-specific binding to the canine transferrin receptor. J Virol 77: 1718-1726

34. Li KS, et al. (2004) Genesis of a highly pathogenic and potentially pandemic H5N1 influenza virus in eastern Asia. Nature 430: 209-213

35. Shukla P, Nguyen HT, Torian U, et al. (2011) Crossspecies infections of cultured cells by hepatitis E virus and discovery of an infectious virushost recombinant. Proc Natl Acad Sci USA 108: 2438-2443

36. Musso D (2015) Zika Virus Transmission from French Polynesia to Brazil. Emerg Infect Dis doi: https:/ / dx.doi.org/10.3201/eid2110.151125

37. Wolfe ND, Dunavan CP, Diamond J (2007) Origins of major human infectious diseases. Nature 447: 279-283
38. Woolhouse M, Gowtage-Sequeria S (2005) Host range and emerging and reemerging pathogens. Emerg Infect Dis 11: 1842-1847

39. World Health Organization (2020) Prioritizing diseases for research and development in emergency contexts. https://www.who.int/activities/prioritizing-diseases-for-research-and-development-in-emergency-contexts

40. Woolhouse ME, Haydon DT, Antia R (2005). Emerging pathogens: the epidemiology and evolution of species jumps. Trends Ecol Evol 20: 238-244

41. Parvez M, Parveen S (2017) Evolution and Emergence of Pathogenic Viruses: Past, Present, and Future. Intervirology 60: 1-7.

\section{Differentiation, emergence and re-emergence of viral pathogens: past, present, future}

\section{Agnieszka Figas $^{\square}$}

\section{Medical Affairs, MSD Poland}

${ }^{\bowtie}$ Corresponding author: agnieszka.figas@merck.com

Key words: adaptation, evolution, emerging, host, pathogen, virus

\section{ABSTRACT}

Viruses and viral diseases have been the subject of interest for science and some of our greatest challenges and achievements are in the field of virology. Cases of emerging and re-emerging infections have posed problems and sometimes enormous public health challenges. Despite significant advances in understanding pathogen biology, the molecular mechanisms of pathogenesis, breakthroughs in the prevention of these infections, and their impact on public health and the global economy, the emergence of new pandemic viruses remains unclear. This review article presents the current state of knowledge on newly emerging viral infections in the world, including recent SARS-CoV-2, MERS, ZIKV epidemics and discussing their possible origins, evolution, natural reservoir, mechanisms of adaptation to the human and potential risk factors. 